\title{
The Role of Combatives Teaching in Physical Education, by Michal Vit and Zdenko Reguli
}

\author{
Wojciech J. CYNARSKI* \\ University of Rzeszów, Faculty of Physical Education, Rzeszów (Poland)
}

Recepción: 02/02/2016; Aceptación: 22/04/2016; Publicación: 28/04/2016.

BOOK REVIEW

\section{Abstract}

There is here a new book, dedicated to the application of martial arts elements in physical education. Sequentially are presented authors, the definition of 'combatives', discussed the contents of the book, pointing out its strengths and weaknesses. A short conclusion is finishing the review article.

Keywords: book review; combatives; physical education; martial arts; combat sports.

\section{The Role of Combatives Teaching in Physical Education, por Michal Vit and Zdenko Reguli Resumen \\ Revisamos un libro dedicado a la aplicación de diversos elementos de las artes marciales en la educación física. La revisión presenta a los autores, la definición de "combatives", discute los contenidos de la obra, señalando sus fortalezas y debilidades, para terminar con una breve conclusión. \\ Palabras clave: Revisión de libro; combatives; educación física; artes marciales; deportes de combate.}

The Role of Combatives Teaching in Physical Education, por Michal Vit and Zdenko Reguli

\section{Resumo}

Fazemos uma revisão do livro dedicado à aplicação de diversos elementos das artes marciais na educação física. A revisão apresenta os autores, a definição de "combatives", discute os conteúdos da obra, assinalando as suas forças e fraquezas, para terminar com uma breve conclusão.

Palavras-chave: Revisão de livro; combatives; educação física; artes marciais; desportos de combate.

\section{Reference \\ Vit, M., \& Reguli, Z. (2015). The Role of Combatives Teaching in Physical Education. Brno: Masaryk University. 128 pp. Retrieved from https://munispace.muni.cz/index.php/munispace/catalog/book/694}

\section{Introduction}

There is here a new book, dedicated to the application of martial arts elements in physical education. As a long-time researcher, and for almost 40 years practice in the field of study (of martial arts, self-defence, and combat sports), I decided to make a review of this publication. Sequentially are presented authors, the definition of 'combatives', discussed the contents of the book, pointing out its strengths and weaknesses. A short conclusion is finishing the review article.

\section{On the authors}

The first Author - PhDr. Michal Vit, Ph.D. - is well known in international society of specialists in area of martial arts and combat sports, as a member of Board of IMACSSS - the International Martial Arts and Combat Sports Scientific Society. He has the practical knowledge, as instructor of Aikibudo ( 3 dan), Kobudo and Kenjutsu Tenshinshoden Katorishinto-ryu ( 2 dan), and self-defence (3 dan). He has the 1 dan in Judo-do/ido what is advanced degree in martial arts. He is a member of Shibu Kobudo IPA, Idokan Poland Association, and co-worker/reviewer of the "Ido Movement for Culture. Journal of Martial Arts Anthropology".

* Email: cynarski@ur.edu.pl. Address: Faculty of Physical Education, Rzeszów University. Towarnickiego str. 3, 35-959 Rzeszów (Poland). 
The second Author - Assoc. Prof. Ph.Dr. Bc. Zdenko Reguli, Ph.D. - is the very well known in the same area, too. He is the Vice-President of IMACSSS and Deputy Editor of the "Ido Movement for Culture. Journal of Martial Arts Anthropology". As teacher of martial arts he is a sensei in Aikido (5 dan), Judo (2 dan), Iaido ( 2 dan), and instructor of self-defence - Goshinjutsu (4 dan). His 2 dan in Judo-do/ido is the evaluation of his advanced degree in martial arts. He is known from interesting works, and also as a good organiser of scientific events, and from achievements in methodology of teaching.

Both Authors are very competent in the subject of using the 'combatives' (martial arts, combat sports, self-defence and combat systems) in physical education, as scientists of physical culture.

\title{
3. On the aims of the book
}

"The publication provides new findings about the current role of combatives in school physical education", as we can read in the Abstract (p. 3). In fact, the book updates the findings about elements of martial arts and combat sports in physical education and expands our current state of knowledge about the description of the "combatives curriculum". It is intended for academics, researchers, as well as for school teachers (p. 4).

The authors present their definition of 'combatives' (to project the meaning):

\begin{abstract}
Combative heritage is so wide, that each culture developed unique combat, fighting, or martial systems. (...) Combatives are connected to physical education and sport more than to military training. Combatives are physical exercises aimed at physical defeat of a partner. Combatives comprise specific exercises which prepare a participant to overcome a partner by physical contact. That means that there must be a direct or indirect contact between at least two persons in a form of punching, grabbing, throwing, and also puling, pushing, or holding somebody; sometimes using shock weapons, such as stick, sword, knife, and so on. No combat using projectile weapons (shooting, throwing) is considered combative according to this definition. (p. 110) (cf. Cihounkova \& Reguli, 2014).
\end{abstract}

According to Wikipedia, 'combatives' is a term for "hand-to-hand combat training and techniques". We can understand, the authors' proposal refers to the use of this term in the context of physical education, sport sciences and martial arts science.

\section{On the contents}

The structure of the book will be discussed first. I believe that 'Introduction' and 'Conclusion' should not be numbered. The book therefore consists of seven chapters. The main chapters are:

2. Method

3. Genesis of combatives

4. Sokol's legacy

5. Foundation of combatives in physical education

6. Illustrative cases of combatives curriculum in physical education

7. Current state of combatives teaching in the Czech Republic

8. Terminological overview of combatives.

Added to these there are several subsections, and: List of figures, List of tables, Bibliography, and Index. Eighty items in the Bibliography are primarily works of Czech and Slovak, but not only. Selection of literature is adequate and sufficient.

The methodology used for this study was at first an analysis of literal sources (literature and documents), and next - an explorative method for pupils $\left(\mathrm{N}_{1}=2813\right)$ and physical education teachers $\left(\mathrm{N}_{2}=151\right)$ (chapter 2).

Historical chapters (3, 4, and 5) present a synthesis of knowledge on the combative tradition in Europe and in the "Sokol" movement. It was a gymnastic society organised firstly in 
Czech, later in some other Slavonic countries (Poland, Slovakia, Slovenia, Ukraine, etc.). The association have been very important for physical culture and patriotic identity of the few nations. Some findings of Sokol's leaders are still interesting for MA\&CS research today (cf. Reguli, 2009).

Own opinions of both authors are right. Interesting (in methodological and cognitive meaning) is their analysis of national physical education curricula of Czech Republic, Slovak Republic and France. We can agree that French system of physical education inspired the establishment of the Sokol system. Czech and Slovak physical education systems, with special focus on combatives, are analysed in chapters 6 and 7.

The authors believe that the all three physical education systems taking into account the combatives (French, Czech and Slovak) are well and correctly prepared (pp. 96-99). However, a freedom in the choice of curriculum, material facilities and teacher qualifications determine the possibility of using combatives in the programmes.

The work is enriched by the figures - the results of the authors' empirical research. This is the result of testing a high number of pupils and physical education teachers, as cited above. In the book there are a total of 36 different illustrations and six tables.

\section{Remarks}

The eighth chapter contains a description of the conceptual language used. This is largely a set of definitions - developed from the Sokol terminology. Due to the range of conceptual arrangements and interactions of basic concepts, this chapter (pp. 110-115) has a special value for the martial arts science, theory of physical education and the science of security.

On the other hand, it lacks in references to the Humanistic Theory of Martial Arts, to which I am pretty much "attached", or also to the Anthropology of Martial Arts (cf. Cynarski, 2012; Zeng, Cynarski, \& Xie, 2013; Cynarski \& Skowron, 2014). Probably the authors tried to emphasize their own idea on combatives theory, based on a series of earlier publications by Z. Reguli (e.g. Reguli, $2004,2009)$. A similar continuity of emphasis applies to issues of didactics.

Book values are especially a synthesis of historical knowledge in the area, a reference to the pan-Slavic tradition of the Falcons (Sokol's organisations), comparing the physical education systems in three countries, and their own suggestions - theoretical concept, conceptual language, and curriculum. The book interestingly promotes the distinctive concept of "combatives" up to now relatively underapplied in sports science.

\section{Conclusion}

This is another rational voice for the dissemination of teaching 'combatives' in the context of school physical education. The book is recommendable to physical education teachers and researchers specializing in this topic. It is also an important item for 'martial arts science', worthy of entry on the IMACSSS' list of recommended literature (www.imacsss.com) and to show it in a network to be freely available.

\section{Acknowledgements}

This work was prepared in the frame of the activity of the Division of Sociology and Anthropology, and Division of Pedagogy, of the IMACSSS.

\section{References}

Cihounkova J., \& Reguli Z. (2014). Combative activities. Brno: Masaryk University.

Cynarski, W. J. (2012). Antropologia sztuk walki: studia i szkice z socjologii i filozofii sztuk walki [Anthropology of martial arts. Studies and essays from sociology and philosophy of martial arts]. Rzeszów: Rzeszow University Press. 
Cynarski W. J., \& Skowron, J. (2014). An analysis of the conceptual language used for the general theory of martial arts - Japanese, Polish and English terminology. Ido Movement for Culture. Journal of Martial Arts Anthropology, 14(3), 49-66. doi: 10.14589/ido.14.3.7

Reguli, Z. (2004). Combative activities. Brno: Paido. Retrieved from http://is.muni.cz/el/1451/podzim2009/bp945/um/Combative PAIDO.pdf

Reguli, Z. (2009). Taxonomy of combatives as it is seen from Tyrš tradition in the Czech Republic. Ido Movement for Culture. Journal of Martial Arts Anthropology, 9, 38-43.

Zeng H. Z., Cynarski W. J., \& Xie, L. (2013). Martial Arts Anthropology, Participants' Motivation and Behaviours. Martial Arts in Chanshu: Participants' Motivation, Practice Times and Health Behaviours. Saarbrücken: Lambert Academic Publishing.

\section{Author's biographical data}

Prof. Dr. Cynarski, full-professor, working at Rzeszów University (Poland), and Head of the Chair of Cultural Foundation for PE, Tourism and Recreation. He has master's degrees in sociology and technical sciences, has carried out post-graduate studies in pedagogy, and has a doctorate and qualifications in the sciences of physical culture (University of Physical Education in Warsaw). He is the founder and president (since 1993) of the Idokan Poland Association, president of IMACSSS, and the editor-in-chief of "Ido Movement for Culture. Journal of Martial Arts Anthropology". He has been practicing martial arts since 1977. Currently he has the title Kaiden Shihan (Menkyo Kaiden) in the Idokan Yoshin-ryu, and is 9th-dan jujutsu, 8th-dan karate, 7thdan aikijutsu, 6th-dan iaido, and 6rd-dan kobudo. E-mail: cynarski@ur.edu.pl. 